\title{
Statued (stat you?) Traditions
}

\section{Selina Tusitala Marsh}

\author{
The 'Golden Past' \\ Is \\ Frozen Fast \\ In \\ anthro-pological \\ socio-logical \\ ethno-graphical \\ historio-graphical \\ feminist-epist-o-mological \\ bio-logical \\ psycho-logical \\ audio-logical \\ edu-cational \\ environ-mental \\ human-biological \\ pharma-co-logical \\ theo-logical \\ gyna-co-logical \\ crimin-o-logical \\ scientifically \\ geothermically \\ text-booked \\ documented
}


locked-fast

bound-cemented

rock-hard

she wears lei

around Gauguinesque

blossoming breasts

sweeping brown

round and around

looping above

firm flat belly button

peeking over

see-thru hula skirt

(not from her island - but what does it hurt?)

she swings her hips

with lips

slightly parted

lip-stick red

with 'come-to-bed' eyes

highlighted by REVLON

black sheen of hair

sweeps the air

(come if you dare

to these mysterious islands)

frozen in glossy post-card form

she is adorned

with dreams

ready for you / to

fantasise

romantisise

over gorgeous big brown eyes

gorging thighs

(gorged out eyes from forging lies!)

'Lovely hula hands'

always understands

make good island wife - for life - no strife

(no hy-phenated name!)

always to sing

island lullaby song

petals caressing wind

all night long 


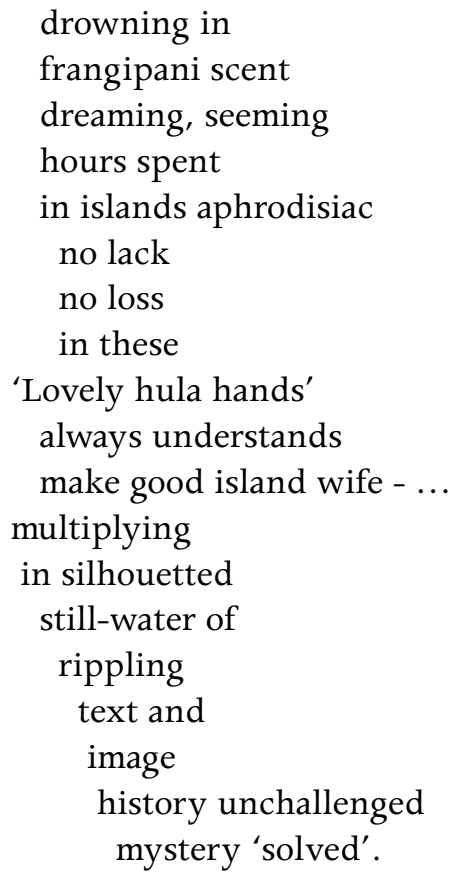

We have evolved

from Noble Savagess

to Tropical Princess

moremore

fantasise

romanticise

mesmerise

metamorphosise your own image

planted before we shed seeds of ourselves in the Pacific

(and not the seed of Margaret Mead nor the semen of Derek Freeman)

Moremore

Fantasise

Romanticise

Frankensize

the monster of you

into

our flesh

stitching parts of islands together:

Solomon beads

Hawaiian lei

Kakala seeds 
of perfume spray from Tonga

Fijian salusalu

Samoan ula

Hawaiian hula

skirt

(you don't wear it that way - but what does it hurt?)

Cook Islands head dress

and coconut breasts

from the Marquesas

(just to please us / and the camera)

'So colourful the way they sit together!'

stat you tradition?

picture post-card / history diagram

stat you tradition?

stat me in you?

Who

is that Pacific Princess?

always waiting

warm bare breasted

anticipating

between 'jungle' leaves

waiting weighting

looking out to sea

fating the sight of you

on the site of me

aaah - moment of 'discovery' -

stat you tradition?

the glossed publications

of island salutations

'Talofa!' 'Kia Ora!'

'Bula Vanaka!' 'Malo e Lelei!'

'Kia Ora Ana!' 'Aloha!' and

'Have a nice day!'

forever static

forever still

motion-less

meaning-less

not my past

not my blessed

genealogical 
'tis fantasy

\& will freeze itself apart

as disciplines crack under heated pressure

of our golden rays

tropical sun melts the haze

breezed island days

blow away petrified images of

no-people

no-where

to-disappear

no need

no more

to hypothesise

theorise

or

romanticise

my tradition is here, within my eyes and those of my mother

For tradition

Eludes

Precludes

Concludes

stasis

tis 'anti-stasis'

ever-moving

ever-grooving

to beaten drum of lali soothing

voices in fagogo telling

tales of old and new

ever-revolving

ever-solving

mysteries of itself

by itself

ever-growing

ever-knowing

of itself and other worlds

incorporating

investigating

revitalising

unto itself 
TOURING PACIFIC CULTURES

$$
\text { indigenising }
$$

outside selves

Statued traditions

stun still water

swimming through

our son and daughter

break the surface

breach the haze

of cemented tradition

of Golden Age

till

looking with new eyes

nothing is left

she on the post-card

has Frozen to death. ${ }^{1}$

1 Previously published in Wasafiri 25 (1997): 52-54. 
This text is taken from Touring Pacific Cultures, edited by Kalissa Alexeyeff and John Taylor, published 2016 by ANU Press, The Australian National University, Canberra, Australia. 